\author{
Barbara Czarnecka \\ Uniwersytet Jagielloński \\ barbara.czarnecka72@gmail.com
}

\title{
Szansa pięknej dziewczyny. Na ścieżce poszukiwania jeszcze jednej kategorii opisu doświadczenia lagrowego i Zagłady kobiet
}

\author{
A Beautiful Girl's Chance. Searching for Yet Another Category in Describing the \\ Women's Experience of Internment and Extermination
}

\begin{abstract}
The experience of the Holocaust and concentration camps has still been insufficiently described in the dimension of gender. The experiences of women and men were different, and so are their respective accounts. The essay A Beautiful Girl's Chance proposes beauty as a category for describing the female experience of internment and extermination. It turns out that reading testimonies and literary texts through such a "filter" of corporeality reveals a lot of examples which show that beauty did play a role in extermination of women.
\end{abstract}

Keywords: extermination, Holocaust, concentration camp, Nazi concentration camp, women, beauty, rapes

Streszczenie: Doświadczenie Zagłady i obozów koncentracyjnych wciąż jeszcze pozostaje niedostatecznie opisane w wymiarze genderowym. Inne były doznania mężczyzn i kobiet, inne też są ich relacje. Esej Szansa pięknej dziewczyny proponuje urodę jako kategorię opisu kobiecego doświadczenia lagrów i Zagłady. Okazuje się, że czytanie świadectw oraz tekstów literackich z wykorzystaniem takiego „filtru” cielesności odsłania bardzo wiele przykładów mówiących o tym, że miała ona wpływ na eksterminację kobiet.

Słowa kluczowe: Zagłada, Holocaust, obóz koncentracyjny, lagier, kobiety, uroda, gwałty

Wiele wskazuje na to, że humanistyka wciąż kreatywnie poszerza pole kategorii opisu doświadczenia lagrowego i Zagłady. Liczne interpretacje wykorzystują niewyeksploatowane metafory, figury i analogie służące pełniejszemu zrozumieniu i odsłonięciu zagadnień przedstawionych dotąd fragmentarycznie. Takie ujęcia to na przykład wybrane studia poświęcone rzeczom czy animal studies. 
Szeroko pojęty przedmiot mojego zainteresowania znajduje się „przed zwrotem postantropocentrycznym”, w sferze historycznoliterackich studiów genderowych jest nim kobiece doświadczenie obozów koncentracyjnych. Jak się wydaje, wielka część kobiecych narracji lagrowych pozostaje niedostatecznie przestudiowana albo co gorsza wcale ${ }^{1}$, a obóz jako przestrzeń życia i umierania kobiet jest stosunkowo słabo poznany ${ }^{2}$. To jeszcze jeden przypadek marginalizacji doświadczenia tej płci, tym bardziej symboliczny, iż już pierwotnie (historycznie) naznaczony wielką, na wielu poziomach przeprowadzoną deprywacją. Z jednej strony spośród funkcjonujących kategorii opisu tego obszaru doświadczeń, niejako automatycznie, wychodzą na plan pierwszy te, które w zrozumiały dla każdego sposób łączą się ze sferą kobiecej psychobiolo-

${ }^{1}$ Interpretacjom najczęściej podlega korpus tych samych, łatwo dostępnych tekstów literackich, w którym powracają autorki: Zofia Kossak Szczucka, Seweryna Szmaglewska, Krystyna Żywulska, Halina Birenbaum, Irit Amiel, Ida Fink. W zasadzie poza zainteresowaniem historyków literatury pozostają relacje świadkiń i dokumenty znacząco poszerzające pole nie tylko samych materiałów źródłowych, ale i interpretacji literatury lagrowej.

${ }^{2}$ Nie znaczy to, że nie istnieją polskie prace na temat kobiet w obozach, na przykład: W. Kiedrzyńska, Ravensbrück. Kobiecy obóz koncentracyjny, Warszawa 1961 (wyd. 2, Warszawa 1965) (to wciąż najważniejsze opracowanie historyczne o społeczności polskich więźniarek w FKL Ravensbrück, najprawdopodobniej od lat przyjmowane bez zastrzeżeń, podczas gdy na przykład w relacji Anny Truszkowskiej-Kuliniczowej czytamy: „Ten podział [polityczny w obozie - dopisek B.Cz.] i brak sympatii znalazł nawet odbicie w książce Wandy Kiedrzyńskiej $R a$ vensbrück, wydanej po wojnie, która osoby z obozu narodowego albo pomija, albo pomniejsza ich działalność, eksponując grupę sanacyjną"), A. Truszkowska-Kuliniczowa, Mój XX wiek. Wspomnienia, Szczecin 2004, s. 93-94); L. Cebo, Więźniarki w obozie hitlerowskim w Oświęcimiu-Brzezince, Katowice 1984; D. Drywa, Zagtada Żydow w obozie koncentracyjnym Stutthof 1939-1945, Gdańsk 2001 - wbrew uniwersalizującemu płcie tytułowi książka w dużej mierze dotyczy losu więźniarek Żydówek; H. Kubica, Kobiety ciężarne i dzieci urodzone w KL Auschwitz, seria Głosy Pamięci, Oświęcim 2010; artykuły Ireny Strzeleckiej w „Zeszytach Oświęcimskich” (1993, nr 20, 2008, nr 24 i 2009, nr 25) poświęcone kobietom w KL Auschwitz-Birkenau i obozach przejściowych, wybrane teksty zamieszczone w „Zeszytach Majdanka”. Brakuje jednak studiów, które uwzględniałyby postmodernistyczny przełom i otwierały się na kobiece doświadczenie w jego pozastereotypowym, pozanormatywnym aspekcie. Rodzime badania historyczne niedostatecznie uwzględniają kryteria feministyczne i genderowe. Niełatwo na przykład uzyskać historyczne informacje na temat kobiecej seksualności i szerzej - na temat specyfiki kobiecego doświadczenia obozów. Referowała między innymi te trudności Joanna Ostrowska na toruńskiej sesji poświęconej nieheteronormatywności; Nie(hetero)normatywność. Narracje. Praktyki. Przedstawienia. UMK 2-4 grudnia 2015. Nawet podstawowe dane źródłowe na temat licznych obozów koncentracyjnych, w większości wypadków opracowywane kilka dekad temu, nie zostały i pewnie nie zostaną pod tym względem przestudiowane powtórnie (bo i jak miałoby to zostać dokonane, wobec ogromu i rozproszenia materiału dokumentacyjnego oraz zanikania materialnych śladów przeszłości). W wypadku wielu opracowań z lat pięćdziesiątych, sześćdziesiątych czy siedemdziesiątych i nawet późniejszych formuła „straty ludzkie” czy „więźniowie obozu" dotyczy obu płci i w wymiarze genderowym niczego nie precyzuje, deficyt ten szczególnie dotyczy mniej „sztandarowych”, często stosunkowo niewielkich obozów koncentracyjnych i miejsc odosobnienia. 
gii $^{3}$ (menstruacja, ciąża i poród, macierzyństwo, golenie włosów, przymusowa nagość), z drugiej jednak strony ich interpretacyjna otwartość wiąże się z ryzykiem ułatwionych wyjaśnień i wskazywania przykładów oczywistych, od dawna będących w czytelniczym obiegu.

Próba czytania narracji lagrowych przez pryzmat kategorii kobiecej urody odbiega od tradycyjnego kanonu znaczeń związanych z doświadczeniem obozu koncentracyjnego i zagłady. Wszak w dyskursie o Zagładzie i w studiach poświęconych obozom ciało jest przede wszystkim dręczone i poniżane. Zbliża się przy tym do męczeńskiego sacrum, co powinno eliminować trywialne pytania. Wystarczy jednak dopuścić tę kategorię (kobieca uroda) jako „filtr lekturowy", a okaże się, że teksty obfitują w rozmaite exempla, oświetlające rzadko wydobywany aspekt rzeczywistości lagrowej4. Oddajmy głos autorce „klasyki gatunku” Sewerynie Szmaglewskiej. W nagłówku tego artykułu przywołuję tytuł jednego z jej opowiadań ze zbioru historii lagrowych zatytułowanego Chleb i nadzieja (1958). Użyte przez autorkę Dymów nad Birkenau sformułowanie „szansa pięknej dziewczyny” wskazuje na ironiczną dwuznaczność sytuacji, jaką w obozie koncentracyjnym stwarzała kobieca uroda. Splatało się tutaj cielesne piękno z wymiernością lagrowego doświadczenia, sposobnością, okazją, możliwością w obozie - czego? Pozostańmy przez chwilę z tym pytaniem, nakierowanym nie na „znaczenie”, ale funkcjonalność, konkretną jej dystynkcję; do samego opowiadania Szmaglewskiej jeszcze wrócimy. Wydaje mi się, że egzystencja lagrowa kobiet pozwala wychwycić zupełnie osobny wątek ich doświadczenia związany z cielesną atrakcyjnością, nazywaną tu przeze mnie pięknością czy urodą, i tak też najczęściej określaną w relacjach lagrowych. Nie jest to studium roli kobiecej urody w doświadczeniu Zagłady, mój zamiar jest dalece skromniejszy i wytyczony przez zaledwie intuicję, że uroda w obozie miewała najczęściej wymiar fatalistyczny.

Zagadnienie urody w związku z Zagładą znalazło również nieoczekiwaną, wydawałoby się kontrowersyjną, kontynuację w prowadzonych w Izraelu od 2012 roku wyborach miss Holocaustu. Kandydatkami na miss są tu kobiety ocalone, które przeżyły rzeczywistość Zagłady, w większości obozy koncentra-

${ }^{3}$ Szkicową ewidencję kobiecych przeżyć okupacyjnych i lagrowych stanowi książka Joanny Stöcker-Sobelman Kobiety Holokaustu. Feministyczna perspektywa w badaniach nad Shoah, Warszawa 2012) Z kolei studium Bożeny Karwowskiej, Ciato, seksualność, obozy zagtady, Kraków 2009, dość wąsko problematyzuje te zagadnienia, między innymi przez kilka metafor kobiecej cielesności; zob. na przykład recenzję Arkadiusza Morawca, Lagry w perspektywie genderowej, „Zagłada Żydów. Studia i Materiały” 2010, nr 6. Zob. jeszcze A. Nikliborc, Uwięzione w KL Auschwitz-Birkenau. Traumatyczne doświadczenie kobiet odzwierciedlone w dokumentach osobistych, Kraków 2010; P. Filipkowski, Historia mówiona i wojna. Doświadczenie obozu koncentracyjnego w perspektywie narracji biograficznych, Wrocław 2010 (tu relacje więźniarek Mauthausen).

${ }_{4}^{4}$ Temat stosowania rozmaitych form przemocy wobec kobiet, również w obozach koncentracyjnych, nie został dotychczas zrekonstruowany przez rodzimą historię. Jest to brak dotkliwy i przekreślający możliwość prowadzenia kompetentnych studiów kulturowych i historycznoliterackich zorganizowanych wokół tego zagadnienia. 
cyjne, wiele z nich ma teraz ponad 90 lat. Konkurs, jak podają prasowe źródła, zorganizowano jako formę kompensacji, psychologiczne antidotum na traumę utraconej młodości. W odpowiedzi na deprywację czasów wojny wybory miss mają stworzyć dawkę potrzebnego kobiecie glamouru. Wybory miss Holocaustu, jak się wydaje, mają też inne znaczenie. Eksponują w widowiskowej, charakterystycznej dla tego typu konkursów, oprawie kobiecą traumę, w przewrotny sposób kojarzą ją z blichtrem i sukcesem urody. Wybierając miss ocaloną, wskazuje się również na indywidualną, konkretną damską wersję Zagłady i w ten sposób, może nieco ekstrawagancko, dowartościowuje doświadczenie kobiece.

$\mathrm{Na}$ początek, za Charlotte Delbo, „spróbujmy spojrzeć, spróbujmy widzieć" ${ }^{\prime \prime}$ wycinek obozu koncentracyjnego w perspektywie płci, tutaj w jakże porażającym jej ujęciu:

Nie czekają dnia. Kolumny natychmiast ruszają. Wpierw kobiety z dziećmi, są najbardziej zmęczone. Potem mężczyźni. Są również zmęczeni, ale czują ulgę, że ich żonom i dzieciom daje się pierwszeństwo.

Bo daje się pierwszeństwo kobietom i dzieciom ${ }^{6}$.

Choć w przeprowadzaniu aktów eksterminacji decydowały względy związane z ekonomią Zagłady, podkreślone przez Delbo pierwszeństwo kobiet i dzieci (do gazu) ma też kulturowy podtekst. Zwyczajowa kurtuazja Europy Zachodniej, wyrażona w zaleceniu „daje się pierwszeństwo kobietom i dzieciom", w tych makabrycznych okolicznościach staje się rodzajem, dosłownie zabójczej, perwersjī. Gest, o pozorach uprzejmości i dobrej woli wobec słabszych (pamiętajmy, że większość ulegała tym pozorom, a Niemcy byli mistrzami mistyfikacji ${ }^{8}$ ), jest w tym „odwróconym świecie”, „kamiennym świecie” przyspieszeniem wykonania wyroku śmierci. Sytuacja ta odsłania bezwzględny, gdyż w określonej kolejności płci doprowadzający do komory gazowej, gender obozu.

5 Takim „metajęzykowym” powtarzającym się zwrotem prowadzi autorka „oko czytelnika”. W tej wyjątkowo sugestywnej prozie kluczowy jest element wizualnej wyobraźni. C. Delbo, Żaden z nas nie powróci, Oświęcim 2002, s. 138.

6 Tamże, s. 14.

7 Nie wszędzie stosowano taką kolejność straceń. W Bełżcu, aby udaremnić ewentualny bunt lub ucieczkę, najpierw gazowano mężczyzn, kobietom i dziewczynkom przedtem jeszcze golono włosy, zob. R. Reder, Betżec, Kraków 1999, s. 48.

${ }^{8} \mathrm{Na}$ Umschlagplatzu wręczano Żydom „wyjeżdżającym do pracy” chleb i marmoladę, w obozach zagłady tworzono pozory istnienia dworca kolejowego z możliwością kupna biletów i poczekalnią, a budynek komory gazowej w Bełżcu opisano szyldem „Bade und Inhalationsräume”, u frontu umieszczono wazon z kwiatami. W łaźniach poprzedzających komory gazowe były ponumerowane wieszaki, aby „właściciele nie zagubili swej odzieży”. 
Różnice płciowe o charakterze biologicznym i kulturowym zostały w obozie sprowadzone do odmiennych sposobów dręczenia i eksterminacji, inaczej też dla mężczyzn i kobiet rozgrywała się dynamika wydarzeń historycznych? Podczas kiedy Delbo przebywała w Auschwitz-Birkenau (rok 1943), płeć stawała się jedną z ważniejszych kategorii selekcji. Choć na początku wojny kobiety pozostawały jeszcze na marginesie eksterminacji, po klęsce Niemców pod Stalingradem i wraz ze wzrostem zapotrzebowania na siłę roboczą częściej gazowano żydowskie kobiety niż mężczyzn ${ }^{10}$. Egzystencja kobiet w obozach koncentracyjnych składała się z różnorodnych elementów nieobecnych w doświadczeniu męskim. Oprócz ciąży i macierzyństwa w ich oczywistym fizycznym wymiarze oraz traumy przeżywania tych stanów w nieludzkich warunkach z kobiecością wiązało się narażanie na niektóre typy eksperymentów pseudomedycznych, na gwałt seksualny (choć nie omijało to też, szczególnie młodych, mężczyzn i dzieci). Kobieca emocjonalność, inaczej niż męska, musiała się zmagać z problemem przeprowadzanej w obozie, na wiele sposobów, degradacji i destrukcji ciała oraz towarzyszącym temu upokorzeniem. Upubliczniona, przymusowa nagość, depersonalizacja przez ogolenie ciała (tak znacząca, iż pozbawione włosów kobiety nie poznawały siebie nawzajem), ogołocenie z rzeczy prywatnych, nie tylko ubrań, ale i pamiątek, zapisały się w kobiecych narracjach obozowych jako doznania z rzędu najgorszych, najbardziej uderzających w poczucie godności i najmocniej dehumanizujących. Kobiecość pociągała też za sobą odmienne niż u mężczyzn taktyki przetrwania, czyli uniknięcia selekcji do gazu przez nadanie młodego i zdrowego wyglądu. Farbowano siwe włosy ${ }^{11}$, malowano usta i policzki albo tuż przed selekcją szczypano się w nie, chcąc wywołać ułudę czerstwości, poprawiano garderobę $^{12}$. Walka o schludny wygląd, wytworzenie wrażenia krzepkości ciała

9 Zob. na przykład A. Pawełczyńska, Wartości a przemoc, Warszawa 1995, s. 56.

10 „Na razie [w 1939 roku - dopisek B.Cz.] kobiety pozostawały na obrzeżach systemu KL zarówno jako strażniczki, jak i więźniarki. Co prawda, ogólny odsetek osadzonych w obozach kobiet rósł szybko - z około 3,3 procent pod koniec lata 1938 do 11,7 procent rok później - ale Ravensbrück wciąż wlókł się daleko w tyle za obozami koncentracyjnymi dla mężczyzn pod względem rozmiarów i surowości. Mimo to jego utworzenie było znaczące, ponieważ zakończyło przejście od bardziej tradycyjnego aresztu ochronnego dla kobiet do nowych form dominacji SS. Obozy dla kobiet były późnym dodatkiem do systemu KL, który został utworzony i scementowany w połowie lat trzydziestych", N. Wachsmann, Historia nazistowskich obozów koncentracyjnych, tłum. M. Antosiewicz, Warszawa 2016, s. 155.

${ }_{11}$ We wspomnieniach z Ravensbrück czytamy na przykład: „Ponieważ zagrożenie stanowiły między innymi siwe włosy, więc zaczęło się masowe farbowanie. Podobno Mietka Jaroszówna Czajka, blokowa na bloku 20, zdobyła farbę, ale o tym dowiedziałam się dopiero z literatury obozowej. W moim otoczeniu używane były wywary z łupin cebuli, z kory drzew przynoszonej przez pracujące w ogrodnictwach lub lesie, względnie czernione węglem. Niektóre nie chciały się poddać takiemu zabiegowi, bo włosy stawały się kolorowe lub szare, ale czasami stanowiło to szansę przeżycia”, A. Truszkowska-Kuliniczowa, dz. cyt., s. 145.

12 „Burak do malowania twarzy był niezawodny. Do przywracania twarzy”, Z. Posmysz, Królestwo za mgta, Kraków 2017, s. 17. „Tak, to selekcja! - zawołała Aërgi do mnie głosem peł- 
były zmaganiem ze śmiercią. Nieoceniona proza Charlotte Delbo znów unaocznia znaczenie w obozie przekonującego wyglądu.

Schneller! Schneller! I Drexler [powinno być Drechsler - B.Cz.] zahaczająca jedną z moich są̧iadek zakrzywioną lagą. Kogo? Nie mogłam sobie przypomnieć, a przecież widziałam szyję zaciskaną od tyłu. Zahaczając laską, Drexler powaliła kobietę, odrzucając ją na bok. Kto to był? (...) Widziałam Panią Brabander w momencie, gdy Drexler zatrzymała ją laską. (...) - Pani Brabander biegła bardzo dobrze. (...) Zmarszczki na twarzy postarzały Panią Brabander. Już się o niej mówi w czasie przeszłym ${ }^{13}$.

Pokrewny mechanizm selekcji decydował o wyborze kobiet do eksperymentów pseudomedycznych. I taką sytuację odtwarza Delbo w scenie obozowego apelu.

Jakiś esesman zbliża się, poznajemy go od razu, to lekarz. Szybko najsilniejsze wślizgują się do przodu, zsiniałe szczypią się w policzki. Zbliża się ku nam, lustruje nas. Czy wie, że jego spojrzenie budzi w nas strach?/ Przechodzi./ Oddychamy./ Trochę dalej zatrzymuje się przed szeregiem Greczynek. Pyta: „Które mają od dwudziestu do trzydziestu lat i urodziły żywe dziecko?"/ Blok doświadczalny potrzebuje świeżych królików./ Greczynki przyjechały niedawno./ My już jesteśmy zbyt długo, kilka tygodni. Za chude lub za słabe, by nam otwierać brzuch ${ }^{14}$.

Do przeprowadzenia pseudomedycznych eksperymentów potrzebne były w miarę zdrowe kobiety, ale na pewno wiemy, że ani młodość, ani zadowalająca kondycja nie gwarantowały ocalenia, nie jest też pewne, w jakim stopniu zwiększały jego szanse. Nader często, jak wiadomo, decydował przypadek. Rzeczywistość gęstniała, gdy w grę wchodziła jeszcze kobieca uroda. Jeśli przyjrzymy się relacjom obozowym, okaże się, że „wybór miss” miał tam miejsce częściej, niż mogłoby się wydawać. A była to najczęściej selekcja do śmierci ${ }^{15}$.

nym rezygnacji: miała oczy zwierzęcia prowadzonego na rzeź. - Tak to selekcja - potwierdziła koścista Elenka i zaczęła poprawiać sobie chusteczkę na głowie, a potem pocierać energicznie twarz, żeby wywołać na niej rumieńce. Niemal wszystkie tak czyniły, pomagając sobie nawzajem w doprowadzeniu się do porządku, do elementarnej, możliwej schludności. Bolące plecy prostowały się siłą woli, niepokój ożywiał oczy, policzki gwałtownie szczypane dostawały kolorków", L. Millu, Dymy Birkenau, tłum. K. Kabatc, E. Kabatc, Oświęcim 2007, s. 42.

${ }^{13}$ C. Delbo, dz. cyt., s. 63-67.

14 Tamże, s. 88.

15 Niemniej z pogromu Żydów na Majdanku 3 listopada wyselekcjonowano nieliczne kobiety i mężczyzn. „Z przeznaczonych na śmierć SS-mani zostawili przy życiu około stu pięćdziesięciu najładniejszych Żydówek i stu młodych Żydów. Zadaniem ich było przeszukiwanie i segregowanie ubrań pomordowanych”; J. Michalak, Nr 3273 miat szesnaście lat, Lublin 1979, s. 260. Ze wspomnień Danuty Brzosko-Mędryk Niebo bez ptaków poznamy historię urodziwej Żydówki Marii, więźniarki Majdanka, ocalonej podczas akcji „Dożynki”. Maria, już jako mężat- 
Atrakcyjny wygląd stwarzał również „szansę” na zatrudnienie młodych kobiet w obozowym puffie. Trudno dociec, czy regułę stanowiło to, że wybierano ładniejsze od innych, czy najistotniejsze były młodość i zdrowie ${ }^{16}$. Puff dawał wątpliwą możliwość przetrwania, ekstremalnie eksploatował i uprawdopodabniał inne rodzaje zagrożenia życia. Dom lalek Yehiel Dinura przedstawia straszny obraz obozowych „oddziałów rozkoszy” formowanych z dziewcząt żydowskich dla zaspokojenia seksualnych potrzeb żołnierzy niemieckich. Przypomnijmy realia pokazane przez Ka-Tzetnika: barak dla dziewcząt, dwa długie rzędy łóżek naprzeciwko siebie, każde łóżko opatrzone numerem, codziennie po południu w dużej grupie przybywają żołnierze, z których każdy ma prawo zareklamować usługę seksualną świadczoną przez konkretny numer, trzy skargi na dany numer oznaczają zagazowanie dziewczyny z przeprowadzoną przedtem pokazową chłostą, do gazu prowadzi też zarażenie chorobą weneryczną, przeciw tej ewentualności nie stosuje się żadnych środków. Do tego burdelu wybrano z getta najatrakcyjniejsze dziewczęta.

Tylko w samych świadectwach ocalonych, zawartych w wydanym w 1945 roku zbiorze Dokumenty zbrodni i męczeństwa ${ }^{17}$, przedstawiono wiele sytuacji, w których o tragicznym wyborze decydowała kobieca uroda właśnie. Oto fragment relacji Tamary Szapiro dotyczącej Majdanka:

Co parę dni selekcja na apelplacu. Przy selekcji kierowano się kaprysem. Szły na gaz starsze, słabe, tlenione, blondynki o aryjskim typie, a przede wszystkim kobiety piękne. Zostawały przeciętne, nierzucające się w oczy ${ }^{18}$.

Taki mechanizm „pierwszeństwa do śmierci” potwierdza więźniarka ocalona z obozu janowskiego (Lwów), Eugenia Mass.

\footnotetext{
ka, z getta warszawskiego trafiła do obozu żydowskiego ,jak inne” (lecz nie zostaje powiedziane jakiego), by stać się w nim bigamistką, żoną legerältestera, organizatora obozowego „Liebeskommanda”, czyli puffu, w którym zaangażowano wybrane dziewczęta. „Młode, śliczne żydowskie dziewczyny o zmysłowych oczach znajdują opiekunów w funkcyjnych. Za opiekę płaci się ciałem, więc wkrótce tworzą się pary”; D. Brzosko-Mędryk, Niebo bez ptaków, Warszawa 1968, s. 303. Z tego obozu wszyscy doprowadzeni zostają na Majdanek. W dniu Erntefest Maria razem z osiemdziesięcioma innym wybranymi dziewczętami zostaje wytypowana do wspomnianej grupy przeznaczonej do segregowania odzieży. Z książki nie dowiemy się, jaki jest dalszy los Marii; tamże, s. 303-308. Narracja historyczna przedstawia to następująco: „Spośród kilkunastu tysięcy ludzi przeznaczonych na śmierć 3 XI 1943 r. pozostawiono przy życiu 300 kobiet i ok. 300 mężczyzn. Kobiety zostały zatrudnione przy sortowaniu odzieży po pomordowanych. W połowie kwietnia 1944 r. prawie wszystkie zostały wysłane do Oświęcimia, gdzie zgładzono je w komorze gazowej”; Majdanek 1941-1944, red. T. Mencel, Lublin 1991, s. 261. Zob. też T. Berenstein, A. Rutkowski, Żydzi w obozie koncentracyjnym Majdanek 1941-1944, „Biuletyn Żydowskiego Instytutu Historycznego" 1966, nr 58, s. 3-57.

16 Zob. M. Röger, Wojenne zwiazki, tłum. T. Dominiak, Warszawa 2016.

17 Dokumenty zbrodni i męczeństwa, red. M. Borwicz, N. Rost, J. Wulf, Kraków 1945.

18 Tamże, s. 70.
} 
W okresie likwidacji ghetta lwowskiego urządził Willhaus przegląd kobiet na placu. Zbliżał się do niektórych i mówił: Du hast schöne Augen, du siehst aus wie eine Arierin, komm - rozstrzeliwał właśnie takie ${ }^{19}$.

W obozie nawet wybitnie „aryjski” wygląd nie stanowił ochrony. W połączeniu z cielesną atrakcyjnością mógł prowokować oprawców, jako przede wszystkim piękno, bez związku z fenotypem „rasy”. „Szansa pięknej dziewczyny” w obozie mogła więc stać się synonimem segregacji.

Uroda kobiet i warunki całkowitej bezkarności wyzwalały zachowania dewiacyjne. Epizod z obozu janowskiego (Lwów) tak relacjonował Abraham Beer:

Widzieliśmy sami jak [Heinen - B.Cz.] m.in. przyprowadził młodą i piękną kobietę pod kuchnię i kazał jej się rozebrać. Zastrzelił ją, a gdy leżała już martwa, strzelił jej jeszcze w łono. Gdy rozstrzeliwał ludzi, był niezwykle ożywiony i podniecony ${ }^{20}$.

Trudno zrezygnować z pytań o przyczynę i celowość takich mordów, nawet jeśli uzyskanie odpowiedzi jest niemal niemożliwe. Klaus Theweleit, niemiecki literaturoznawca, teoretyk kultury i pisarz, poddał refleksji nazizm i jego przejawy z perspektywy relacji płci. W faszyzmie i działaniach mających na celu eksterminację „podludzi” uchwycił mechanizm i zidentyfikował reprodukcję rzeczywistości historycznej nasyconej takim właśnie, przemocowym i seksualizującym, stosunkiem do ciała. Jako jedno ze źródeł bestialstwa wobec kobiet wskazał patologiczną dyscyplinę, jakiej poddane były pokolenia niemieckich mężczyzn od czasów Fryderyka Wilhelma. Według badacza spełnienie i poczucie wolności zyskiwali oni poprzez różne formy „rozprawienia się" się z niepokojącą kobiecością, jej płciową odmiennością, seksualną siłą i erotyczną atrakcyjnością.

Kobiety niepasujące do żadnego dobrego obrazu automatycznie podpadają pod kategorię „popęd” albo „dziwka”; są to istoty podstępne i nastawione na kastrowanie. Trzeba więc odpowiednio do tego je traktować. Mężczyźni, żołnierze, których życie jest „walką”, nie czekają, aż im samym zdarzy się coś potwornego. Atakują, zanim taka kobieta zyska sposobność urzeczywistnienia swych strasznych zamiarów ${ }^{21}$.

19 Tamże, s. 33.

20 Tamże, s. 30.

${ }^{21}$ K. Theweleit, Męskie fantazje, tłum. M. Falkowski, M. Herer, Warszawa 2015, s. 179. Warto wspomnieć, że tezy Klausa Theweleita, opublikowane w Niemczech pod koniec lat siedemdziesiątych, spotkały się z krytyką historyków, a książka pojawiła się w atmosferze skandalu, zob. na przykład J. Borowicz, Nagość $i$ mundur. Ciato w filmie Trzeciej Rzeszy, Warszawa 2015, s. 27-31. 
Akty sadystycznego mordu Theweleit interpretuje dwojako. Po pierwsze symbolicznie, jako stosunek płciowy. „Niszczy on genitalia zmysłowej kobiety, które - jak widzieliśmy - są dla żołnierza źródłem kastracyjnego zagrożenia"22, po drugie, jako moment autentycznego seksualnego zaspokojenia.

Jest tak, jak gdyby kobietę rozszarpywały jednocześnie dwa przymusy, jakim podlegają mężczyźni: jeden przymus każe im ją oddalić, trzymać z daleka od siebie (obrona), drugi zaś - wniknąć w nie, przyciągnąć jak najbliżej. Oba te kompulsywne pragnienia zdają się zaspokojone w akcie mordu - mężczyzna odpycha kobietę jak najdalej (pozbawia ją życia), a jednocześnie ma ją całkiem blisko przy sobie (wdziera się w nią za pomocą strzału, pchnięcia, ciosu kolbą itd.). Ową bliskość umożliwia fakt, że kobiecie odebrano tu status obiektu o trwałym kształcie i konkretnym imieniu. Właśnie to pozwala mężczyźnie odetchnąć - kobieta przestaje być tym wszystkim i zamienia się w breję, bezkształtną krwawą miazgę. (...) Dokonuje się tu likwidacja ciała jako ciała, zniesienie kobiety jako ciała ludzkiego i - co za tym idzie - jako miłosnego obiektu ${ }^{23}$.

Jak się wydaje, szczególnie zasługuje na uwagę konstatacja badacza o odebraniu kobiecie jej podmiotowości, zatem „kształcie i konkretnym imieniu”, ponieważ uroda kobiety nie oznaczała w obozie szans jej indywidualizacji24. Podobało się piękne ciało i, często właśnie z tego powodu, mordowano piękne ciało tego właśnie człowieka. Powrócę do tego wątku w cytowanym nieco dalej fragmencie opowiadania Tadeusza Borowskiego. Oddajmy teraz głos Esterze Gold więzionej w obozie w Skarżysku-Kamiennej i Adolfowi Wolfgangowi z więzienia w Szebniach.

\section{Estera Gold:}

Gdy szef Bartenschlaeger urządzał selekcję, opróżniał prawie cały szpital, wyciągał z szeregów źle wyglądających lub źle ubranych, znęcał się nad dziewczętami. Co jakiś czas wybierał najpiękniejsze, gwałcił je, zabijał sam, a potem kazał grzebać w lesie ${ }^{25}$.

\section{Adolf Wolfgang:}

Pod koniec apelu, który trwał jedną do dwóch godzin, komendanci i szefowie oraz uczestnicy „Scheidtowskiej” zabawy wybierali młode i piękne dziewczęta pod pretekstem „sprzątania” we dworze. Tam nie obowiązywała Rassenschtande. Po takim nocnym sprzątaniu dziewczęta wracały z opuszczonymi głowami, ukradkiem ocie-

${ }^{22}$ K. Theweleit, dz. cyt., s. 200.

23 Tamże, s. 200-201.

${ }^{24}$ Przywracanie ofiarom pamięci podmiotowej jest jednym z celów dyskursu o Zagładzie, zob. na przykład S. Ruszkowska, Każdemu wtasna śmierć, Warszawa 2014.

${ }^{25}$ Dokumenty zbrodni i męczeństwa, dz. cyt., s. 50. 
rając łzy. Były wypadki stawiania oporu, niektóre odważniejsze próbowały bronić czci, lecz przypłaciły to życiem. Oto jedna z zabaw „Scheidtowskich”. P.M. z Krakowa, fryzjer w sztabie niemieckim, otrzymał rozkaz, by natychmiast wybrał do obozu jedną z dziewcząt, przyprowadził ją i w obecności sztabu był wraz z nią obiektem zdjęć pornograficznych ${ }^{26}$.

\section{Adolf Wolfgang:}

Gdy nadchodziły transporty Żydów, odbywały się rewizje z największą skrupulatnością. Były to straszne chwile, wykorzystywane dla ohydnych zboczeń, tortur i morderstw. Wybrano specjalnie do tej funkcji 20-tu Niemców pod kierownictwem osławionego Berndta oraz Unterfurera, który miał kilkuletnią praktykę w obozie Dachau. Rewizję przeprowadzali nago, więcej trudu zadawali sobie z kobietami, szczególnie gdy były młode i dobrze zbudowane, rewizja trwała dłużej. Kobiety takie musiały nago tańczyć i wyginać się na wszystkie strony. Wiele razy sam komendant obozu Scheidt, człowiek o najniższych instynktach zwierzęcych, przychodził wieczorami wraz ze swą świtą do baraków zamieszkałych przez Żydówki, wybierając spośród nich najpiękniejsze, celem rzekomego przeprowadzenia rewizji osobistej ${ }^{27}$.

Kobiety piękne wielokrotnie doświadczały sadyzmu i rozmaitych form dehumanizującej perwersji. Jak wynika z relacji ocalonych, istota tych sytuacji są ekstremalne formy zniewolenia i poniżenia kobiet, większość z nich potem zabito. Aby uniknąć tego rodzaju zakłóceń obozowej dyscypliny, Heinrich Himmler zadecydował, że w ośrodkach koncentracyjnych dla kobiet zatrudniony zostanie damski personel. Tak zorganizowano modelowy obóz, jakim był Ravensbrück, podobnie funkcjonowały późniejsze obozy koncentracyjne i ich podobozy dla kobiet. Jak wiemy, nie eliminowało to wielorakich form zwyrodniałego sadyzmu wobec więźniarek.

Również niemieckie kobiety (także piękne) wykorzystywały swoją przewagę funkcyjnych dla zaspokojenia potrzeby seksualnej agresji i wcielały się w oprawczynie. Irma Grese, od 1943 roku strażniczka, potem zastępczyni nadzorczyni obozu kobiecego w Auschwitz-Birkenau, znana ze zwracającej uwagę urody i nieustępującego jej stopniem okrucieństwa, nazwana została „piękną bestią" ${ }^{28}$. Ilse Koch, żona komendanta obozu w Buchenwaldzie, ujawniała dewiacyjny stosunek wobec więźniów płci męskiej i nie bez powodu zyskała przydomek „wiedźmy z Buchenwaldu”. Przeszła do historii jako fetyszystka przedmiotów wykonanych, na jej zamówienie, z ludzkiej skóry. Wiadomo również, że przechadzała się w pobliżu więźniów w prowokacyj-

26 Tamże, s. 35.

27 Tamże, s. 36.

${ }^{28}$ D.P. Brown, Piękna bestia. Zbrodnie SS-Aufseherin Irmy Grese, tłum. J.S. Zaus, Warszawa 2017. 
nych strojach, wybierała spośród nich atrakcyjnych kochanków, by później doprowadzić do ich mordu ${ }^{29}$. Można by z pewnością analogicznie rozpatrywać „szansę najpiękniejszego mężczyzny”, zresztą do niej właśnie sprowadzała się funkcja pipla ${ }^{30}$.

Uderzające jest jednak to, że seksualna agresja kobiet funkcjonuje w innym schemacie kulturowym niż męska. Wyłamuje się z „naturalnego”, „ludzkiego" porządku i od razu wpisuje w monstrualną dewiacyjność, dlatego postaci tych kobiet tak bardzo przykuwają uwagę i nazywane są one wiedźmami i bestiami ${ }^{31}$, podczas gdy mężczyźni zaspakajają „jedynie” „męskie fantazje”, by odwołać się do tytułu opracowania Kurta Thewelaita.

Częścią Männerphantasien jest również perwersyjna maskarada, w której żydowskie więźniarki zmuszone są przez Niemców do odgrywania ról tancerek i fordanserek.

\section{Szebnie, Adolf Wolfgang}

Po skończonej „akcji” gestapowcy wzywali „pucerów”, by im oczyścić buty, gdyż były całe we krwi, po czym rozpoczynała się libacja, która trwała do rana. Podczas zabawy usługiwały im Żydówki, które musiały być zarazem tancerkami. Szefowie gestapo i policji całowali je po rękach, aby je później w pierwszych szeregach rozstrzelać $^{32}$.

Od momentu wprowadzenia w życie ustaw norymberskich obcowanie $\mathrm{z}$,niższą rasą” było surowo zabronione, ale w warunkach okupacyjnych i obozu zakaz łamano nader często w rozmaitych formach, a towarzyszące mu akty przemocy i bestialstwa pozostawały bezkarne. W opisywanych scenach warto być może zwrócić uwagę na element dewiacyjnej teatralizacji, dansingowej kurtuazji wobec przyszłych ofiar. Wyreżyserowana przez niemieckich mężczyzn ewidentna gra w dżentelmenerię i dworność na moment zawieszała, unieważniała status Żydówek jako Untermenschen. Symboliczne jest chwilowe, w bestialskiej grze prowadzonej dla rozrywki oprawców, pozorne wydźwignięcie tancerek na poziom atencji „aryjskich” Niemców („całowali je po

${ }^{29}$ Zob. na przykład F. Whitlock, Bestie z Buchenwaldu, tłum. M. Fafiński, Zakrzewo 2014; J. Green, Sprawiedliwość w Dachau. Opowieść o procesach nazistów, tłum. M. Antosiewicz, Warszawa 2012.

${ }^{30}$ Zob. H. Heger, Mężczyźni z różowym trójkątem. Świadectwo homoseksualnego więźnia obozu koncentracyjnego 1939-1945, tłum. A. Rosenau, Warszawa 2016. Być może warto tu przypomnieć, że Yehiel Dinur, autor słynnego Domu lalek, jest też autorem, nietłumaczonej jak dotąd na język polski, książki Piepel, o wykorzystywaniu seksualnym młodych chłopców.

${ }^{31} \mathrm{Na}$ miano bestii zasłużyła na przykład niemiecka nadzorczyni w obozach dla kobiet i kierowniczka kobiecej części Auschwitz-Birkenau Maria Mandel, opisywana jako „Złotowłosa, dorodna kobieta o oczach bestii”; M. Rutkowska-Kurcyuszowa, Kamyki Dawida. Wspomnienia, Katowice 2005, s. 160.

32 Dokumenty zbrodni i męczeństwa, dz. cyt., s. 37. 
rękach") i następujące potem strącenie w otchłań hierarchii, na której końcu znajdowała się żydowska kobieta i jej śmierć.

Wydaje się, że często działał też prosty mechanizm karania za urodę, kobiety przydzielano wtedy do najintensywniej, najszybciej wyniszczających prac. Na podstawie przeżyć z obozu w Skarżysku-Kamiennej tak relacjonowała Felicja Bannet:

Najpiękniejsze młode dziewczęta, blondynki o szczególnie pięknych rękach, wybierano do najgorszej pracy, do pikryny; przy niej od razu zoółkły jak kanarki, a ręce pokryte były wrzodami. Nikt nie chciał starych kobiet ${ }^{33}$.

Prawie jednakowa w treści i brzmieniu jest relacja Róży Bauminger Przy pikrynie $i$ trotylu, innej ocalonej więźniarki z tego obozu, zapewne przyczyną tej zbieżności są korekty redakcyjne, w obydwu wypadkach dokonane przez kolegium o podobnym składzie.

Podczas pierwszego apelu, kiedy odbywało się przydzielanie do poszczególnych hal, nikt nie chciał starszych robotnic. (...) Do tej pracy wybierano młodych i zdrowych mężczyzn i młode dziewczęta, blondynki, o pięknych nieraz rękach. Przy tej pracy żółkły jak kanarki, a ręce ich pokrywały się wrzodami ${ }^{34}$.

I w tym wypadku młodość i uroda zapewniały raczej pierwszeństwo w kolejce do śmierci. Pikryna to trucizna (środek chemiczny wykorzystywany przy produkcji materiałów wybuchowych), a warunki pracy z nią związane były najgorsze w całym obozie ${ }^{35}$. Czy można poza tym wyobrazić sobie okrutniejszą przemyślność niż tę, która na spektakularne wyniszczenie i natychmiastową zmianę wyglądu (dewastacja ciała następowała już po jednej przepracowanej dniówce) skazywała kobiety właśnie młode i ładne? Pojawiały się trudności z oddychaniem, torsje, na skórze tworzyły się rany, ciało zmieniało kolor. „Kobiety rudo czerwone (działanie pikryny na włosy) o czerwonych paznokciach, nawet oczy na żółtej twarzy robiły wrażenie żółtych”36. „Pikryniarze” musieli przebywać w osobnych barakach, nie dostawali koców, bo żółkły, unikali ich inni więźniowie, ponieważ wszystko wokół nich barwiło się i nabierało gorzkiego smaku. Oprócz napiętnowania dochodził więc element przymusowej

33 Tamże, s. 39.

${ }^{34}$ R. Bauminger, Przy pikrynie i trotylu, Kraków 1946, s. 27-28.

35 „Największa groza i nędza panowała na Sali 13-tej osławionej na wszystkich trzech werkach. Fabrykowano tam miny podwodne napełniane pikryną, proszkiem bardzo szkodliwym dla organizmu, od którego wszystko żółknie i gorzknieje. (...) Podczas gdy przy lżejszej pracy panowały znośniejsze warunki i pewna solidarność, przy pikrynie wytworzyło się wzajemne bezwzględne traktowanie. (...) Podczas likwidacji lagru wykończono wszystkich pikryniarzy, bo Niemcy nie chcieli pokazać światu żółtych ludzi”, tamże, s. 28-32.

36 Tamże, s. 21. 
separacji. Na zbliżonej zasadzie najprzystojniejszych mężczyzn zatrudniano w obozach w Scheisskomandach. Podobny dobór występował też w trakcie mordów prowadzonych przez działających na wschodzie Einsatzgruppen. Przeczytajmy opis wydarzeń rozgrywających się na przedmieściach Kowna po operacji „Barbarossa” i wcieleniu tej części Litwy do Trzeciej Rzeszy. Oprawcami Żydów są tutaj Litwini. Oto świadectwo ocalałej kobiety.

Kobiety natychmiast zabrano do podziemnych koszar, gdzie kazano nam się położyć na gołym betonie, jedna na drugiej. Przez wiele dni leżałyśmy tak bez pożywienia i wody. Nie pozwolono nam wyjść na zewnątrz. Dzieci płakały i zawodziły, pytając matek, dlaczego nie mogą wrócić do domu. Co słabsze kobiety mdlały z pragnienia i od potwornego zaduchu. Jednak noce były jeszcze gorsze niż dni. Wtedy przychodzili partyzanci z latarkami i grabili kobiety z kosztowności. Później przychodzili inni i bili je, gdyż już nie miały co im dać. Ulubionym rodzajem rozrywki było zmuszanie kobiet do tańczenia nago. Kiedy się już wystarczająco podniecili, wybierali co ładniejsze i zabierali siłą, by zgwałcic ${ }^{37}$.

Prześledźmy jeszcze historyczny komentarz autora, który następuje dalej: „Niektóre ze zgwałconych kobiet były później mordowane. Jednakże SS nie było jeszcze wtedy gotowe, by ryzykować masowe morderstwa kobiet i dzieci. Na razie te, które przeżyły pobyt $\mathrm{w}$ forcie, zostały wypuszczone na wolność i wróciły do Kowna"38

Krzysztof Dunin-Wąsowicz, były więzień obozu Stutthof i autor wielu historycznych opracowań dotyczących tego lagru, opisuje los pierwszych transportów z Białorusi i Ukrainy oraz pięknych kobiet.

Przywieziono także kobiety, które dostały osobny barak. Kobiety te traktowano początkowo okropnie. Kazano im wykonywać najohydniejsze prace: wywozić ekskrementy ludzkie i gnój. Często co ładniejsze dziewczęta esesmani zabierali do siebie na noc. Jeszcze częściej robili to niemieccy kapowie i blokowi ${ }^{39}$.

Świadectwa takie jak powyższe czy Dokumenty zbrodni i męczeństwa mają charakter szczególny. Będąc rodzajem martyrologium, są jednocześnie, stworzonym przez zgromadzenie licznych relacji z różnych obozów koncentracyjnych „sytuacyjnym przeglądem”, pozbawionym naddatków literackich, sprowadzonym do opisu faktów. Rzec również można, że to bestiariusz nazizmu, w którym w wielu odsłonach jawią się też straszne „szanse najpiękniejszej”.

${ }^{37}$ Cyt. za: R. Rhodes, Mistrzowie śmierci. Einsatzgruppen, tłum. M. Urbański, Warszawa 2015, s. 67.

${ }^{38}$ Cyt. za: tamże.

39 K. Dunin-Wąsowicz, Obóz koncentracyjny Stutthof, Gdynia 1966, s. 92. 
Wątek kobiecej urody determinującej los powraca i w literackich, męskich oraz kobiecych, narracjach o obozie i Zagładzie. Głos chcę tutaj oddać dwu autorkom, Sewerynie Szmaglewskiej (zbiór opowiadań Chleb i nadzieja) i Lianie Millu (zbiór opowiadań Dymy Birkenau).

Wspomniane już na wstępie opowiadanie Szmaglewskiej Szansa pięknej dziewczyny najprawdopodobniej zainspirowane jest faktem, który powraca w bardzo wielu relacjach i ujęciach. Chodzi o osławioną śmierć SS-mana, jednego z kierowników obozu Auschwitz, Josefa Schillingera, zadaną mu przez kobietę przed wejściem do komory gazowej. Przypomnijmy kilka wersji tego zdarzenia.

Tadeusz Borowski:

Wszystko poszłoby jak należy, ale Schillingerowi spodobało się jedno ciało, rzeczywiście - klasycznie zbudowane. Pewno po to przyjechał do szefa. Podszedł więc do kobiety i wziął ją za rękę. Wtedy naga kobieta nagle schyliła się, zaczerpnęła w dłoń piasku i sypnęła mu w oczy, a kiedy Schillinger krzyknąwszy z bólu, puścił z ręki rewolwer, kobieta pochwyciła broń i strzeliła Schillingerowi kilka razy w brzuch ${ }^{40}$.

Wiesław Kielar:

Stała się rzecz niebywała. W nocy, w czasie likwidowania jednego z licznych transportów, został zastrzelony Oberscharfürer Schillinger. (...) Wieść rozeszła się lotem błyskawicy po całym obozie, wywołując ogólny radosny nastrój. (...) Schillinger, jak zwykle gorliwy, asystował przy przyjmowaniu nocnego transportu Żydów na rampie w towarzystwie swego koleżki, Hauptscharfürera Emmericha. Obaj, podchmieleni, konwojowali transport aż do krematorium. Weszli nawet do rozbieralni, powodowani bądź perspektywą łatwej grabieży, bądź sadystycznym upodobaniem napawania oczu widokiem wystraszonych, bezbronnych, obdartych z szat kobiet, mających za chwilę skonać w męczarniach w komorze gazowej. (...) Jego uwagę zwróciła jedna z młodych i podobno pięknych kobiet, która w obecności esesmanów nie chciała rozebrać się do naga. Rozjuszony tym Schillinger zwrócił się do kobiety, usiłując zerwać jej stanik ${ }^{41}$.

\section{Szlomo Dragon:}

Schillinger odwrócił się i wrzasnął... Nie, rozebrać się do naga i wycelował pistoletem w biustonosz. Kobieta zdjęła biustonosz, rzuciła nim Schillingerowi w twarz, ale trafiła go w ramię. Pistolet wypadł mu z ręki na ziemię. Kobieta prędko go pod-

40 T. Borowski, Śmierć Schillingera [w:] tegoż, Pożegnanie z Maria i inne opowiadania, Wrocław 2010, s. 231.

${ }^{41}$ W. Kielar, Anus mundi, Wrocław 2004, s. 247. 
niosła, wycelowała w Schillingera i zastrzeliła go na miejscu. (...) Chodziły słuchy, że była aktorką, ale nigdy nie dowiedzieliśmy się, kim była naprawdę ${ }^{42}$.

Aktorka, o której była mowa, to najprawdopodobniej Franciszka Mann, uważana była za współpracownicę żydowskiej policji, pomimo to wymienia się ją zwykle w kontekście opisanego wydarzenia ${ }^{43}$. W literackiej wersji Szmaglewskiej tytułowa piękna dziewczyna nosi imię Madelaine i jest żydowską aktorką narodowości francuskiej, osadzoną w przejściowej części obozu zwanej Meksykiem. Pomimo wyniszczenia wyróżnia się postawą i urodą:

Prowadzono Meksyk. (...) Widziałem na wprost siebie Madelaine. Była piękna jakimś rzadkim i cennym rodzajem urody. Nędza tutejszej egzystencji nie tknęła jej lśniących włosów ani smagłego ciała. Byłem zdumiony. Nie widziałem kobiety, która by pozostała sobą w obliczu zagłady, po przejściu całej ohydy transportu i czekania na niewiadome. (...) Na wprost siebie miała małą grupkę hitlerowców, a całkiem blisko niej stał ten młody w uniformie gołębiej barwy. Zabawiał się pistoletem tak swobodnie, jak by to były rękawiczki. Nie odstępował jej. Kiedy pochód ruszył, od szedł także przy jej ramieniu. Pytał ją o coś, a może tylko dotykał wzrokiem jej urody. Ciągle zwracał się do niej. Obserwował jej ruchy. Z ironią rejestrowałem podniecenie samca, który nie kryje, że uległ urokowi spotkanej kobiety. Każdy krok przybliżał Madelaine do krematorium. Ale jej los ważył się jeszcze w tej chwili. Zyskała niezwykłą wśród ludzkiego maku szansę, szansę pięknej kobiety. Bywały wypadki, że odsyłano z rampy do obozu jakąś dziewczynę, nie zajmując się nią dłużej. Kiedy indziej zatrudniano jako służącą lub kierowano do domu publicznego albo do tego lepszego, dla hitlerowców. Wiedziałem, że transporty z Meksyku na ogół nie podlegały już selekcji. W ten sposób znikała wszelka nadzieja. Ta dziewczyna zginie, jeżeli zainteresowanie hitlerowca okaże się przelotne. (...) Wiadomość nadeszła błyskawicznie. Podawano ją z ust do ust. Anwajzerzy, blokowi, kapo wymawiali niemal te same słowa: „Położyła go na miejscu. $Z$ jego własnego pistoletu!” Był w tym podziw i satysfakcja. Wszyscy, najnędzniejsi nawet, podobni cieniom więźniowie chcieli sami usłyszeć, a później innym powtarzać szczegóły: „Paryż... Aktorka... Madelaine...”44.

W literackiej wersji zdarzeń autorstwa Szmaglewskiej naddatek artystyczny pozostaje czytelny. Choć wymowa tej narracji jest absolutnie tragiczna, to jednak nagość faktów zostaje osłonięta epicką warstwą, zorganizowana fabularnie itp. Najbliżej dobitności puent niemieckiego badacza Theweleita znaj-

${ }^{42}$ G. Greif, ...ptakaliśmy bez tez..., tłum. J. Kapłon, Warszawa-Oświęcim, 2001, s. 149$150,231$.

43 A. Dobrowolska, Fotograf z Auschwitz, Warszawa 2013, s. 167.

${ }^{44}$ S. Szmaglewska, Szansa pięknej dziewczyny [w:] tejże, Chleb i nadzieja, Warszawa 1960, s. $50-53$. 
duje się Tadeusz Borowski, właśnie w Śmierci Schillingera rolę gra nie kobieta, jako osoba, podmiot, ale kobiece ciało, jego urok i proporcje. Widać to odpersonalizowanie, podwojone niejako, w literackim scenariuszu opowiadania Borowskiego: Schillingerowi „spodobało się jedno ciało”, narrator (za znajomym vorarbaiterem z sonderkomanda) potwierdza „ciało było klasycznie zbudowane".

Uroda więźniarek była stanem wyjątkowo krótkotrwałym, kobiety z południa Europy, nieprzystosowane do surowych warunków klimatycznych traciły ją już po kilkunastu dniach pobytu w obozie. Te, które przeżywały kwarantannę i podejmowały pracę w komandach, szybko traciły na wadze, mizerniały, chorowały. Uroku nie dodawały też niedbale, nierówno ogolone głowy. Nie podlegały tej degradacji funkcyjne, syte, często dobrze ubrane, z ufryzowanymi włosami. Ale i więźniarka z Węgier, Lilly przedstawiona w opowiadaniu Liany Millu Lilly Marlene, jakby się jej opierała. Zawsze wyjątkowo świeża i starannie, jak na warunki obozowe, ubrana („- Jakaś ty piękna, jakaś elegancka! - stwierdziłam z uznaniem" ${ }^{45}$ ) zwróciła na siebie uwagę niemieckiego kapo zaangażowanego w romans z kapówką jej komanda. Historia przedstawiona przez Millu nie jest długa - zazdrość kapówki i jej wyrok śmierci na Lilly:

- To ta, Herr Doctor - powiedziała, wskazując na Lilly. - Zawsze kaputt. Nie może pracować. - Wystąp - powiedział spokojnie Mengele, dając znak, że ma wyjść z szeregu. I Lilly wyszła ${ }^{46}$.

I o Madelaine, bohaterkę opowiadania Szmaglewskiej, z zazdrością, wypytuje blokowa.

Kobiety przedstawione w relacjach i dokumentach, choć mają „swoją twarz i imię", jako podmioty relacji znikają w jednym momencie - oddania strzału, wymierzenia ciosu itp. - z planu opowieści. Bohaterki literackie, choć występują w podobnych rolach, dłużej i, by tak rzec, szerzej, w bardziej rozległym planie, utrzymywane są przy życiu. Zarówno Lilly, jak i inne bohaterki opowiadań Millu mają swoją genealogię, wiemy, kim były przed wojną, jakie mają osobowości, w jakich relacjach rodzinnych i współwięźniarskich są osadzone. Ten literacko zbudowany kontekst postaci może jednak oddziaływać na czytelnika w ten sposób, że nieco uchodzi jego uwadze fakt bezwzględności mechanizmu eliminacji.

Świadectw, i tyleż literackich wersji obozowego koszmaru istnieje nieporównywalnie więcej, niż tu omówione. Najprawdopodobniej nigdy nie dowiemy się, w jakim stopniu przedstawione sytuacje stanowią schematy dokonanych wydarzeń, zapewne można się spodziewać od nich odstępstw, wszak na

\footnotetext{
45 L. Millu, dz. cyt., s. 13.

46 Tamże, s. 44.
} 
„innej planecie” obozu nie obowiązywały reguły. Być może w wielkiej „szansie najpiękniejszej”, czyli uprawdopodobnieniu wyjątkowego prześladowania albo śmierci, ujawniał się społeczny, darwinistyczny mechanizm degradacji tego, co wyjątkowe. Bo przecież literalnie odwzorowuje gaussowski rozkład prawdopodobieństwa, wcześniej już cytowane zdanie, wypowiedziane przez jedną z ocalałych: „Zostawały przeciętne, nierzucające się w oczy”.

Niepokojący jest brak symetrii $\mathrm{w}$ ramach płci kulturowej. Primo Levi w Czy to jest cztowiek? stwierdzi, że zwykły häftling (rodzaju męskiego) nie miał szans przeżycia. „Pozostali tylko lekarze, krawcy, szewcy, muzykanci, kucharze, atrakcyjni młodzi homoseksualiści, przyjaciele lub współrodacy jakiegoś potentata obozowego (...)" ${ }^{\text {‘7 }}$. To ustalenie nie mogłoby zostać rozszerzone o atrakcyjne młode kobiety. Wyjątkową naiwnością byłaby oczekiwanie, że urodziwe kobiety pozostawiano przy życiu. Zdanie: „była tak piękna, że wypuszczono ją z komory gazowej i darowano życie” okazuje się w kontekście faktów kompletnym nonsensem, odzwierciedlającym jeszcze jedną ciemną stronę genderowych różnic. Nieco więcej światła mogłoby rzucić gruntowniejsze badanie tej problematyki. Tutaj pragnęłam jedynie skierować na nią uwagę i zaledwie sformułować tezę, że uroda kobiet nie była bez znaczenia dla ich eksterminacji.

Niech fenomenalna Delbo będzie ramą tego eseju.

Jej ojciec, matka, bracia i siostry zostali zagazowani zaraz po przyjeździe./ Rodzice byli za starzy, dzieci za młode./ Mówi: „Śliczna była moja młodsza siostra./ Nie możecie sobie wyobrazić jaka była śliczna./ Nie spojrzeli na nią./ Gdyby spojrzeli na nią, to by jej nie zabili./ Nie mogliby" ${ }^{4}$.

\section{Bibliografia}

Bauminger R., Przy pikrynie i trotylu, Kraków 1946.

Berenstein T., Rutkowski A., Żydzi w obozie koncentracyjnym Majdanek 19411944, „Biuletyn Żydowskiego Instytutu Historycznego” 1966, nr 58.

Borowicz J., Nagość i mundur. Ciato w filmie Trzeciej Rzeszy, Warszawa 2015.

Borowski T., Pożegnanie z Maria i inne opowiadania, Wrocław 2010.

Brown D.P., Piękna bestia. Zbrodnie SS-Aufseherin Irmy Grese, tłum. J.S. Zaus, Warszawa 2017.

Brzosko-Mędryk D., Niebo bez ptaków, Warszawa 1968.

Cebo L., Więźniarki w obozie hitlerowskim w Oświęcimiu-Brzezince, Katowice 1984.

Delbo C., Żaden z nas nie powróci, Oświęcim 2002.

${ }^{47}$ P. Levi, Czy to jest cztowiek, tłum. H. Wiśniowska, Kraków 1978, s. 87.

48 C. Delbo, dz. cyt., s. 52. 
Dobrowolska A., Fotograf z Auschwitz, Warszawa 2013.

Dokumenty zbrodni i męczeństwa, red. M. Borwicz, N. Rost, J. Wulf, Kraków 1945.

Drywa D., Zagtada Żydów w obozie koncentracyjnym Stutthof 1939-1945, Gdańsk 2001.

Dunin-Wąsowicz K., Obóz koncentracyjny Stutthof, Gdynia 1966.

Dzieci i więźniowie matoletni w obozie KL Stutthof, oprac. Janina Grabowska, „Zeszyt Muzeum Stutthof” 1977, nr 2.

Filipkowski P., Historia mówiona $i$ wojna. Doświadczenie obozu koncentracyjnego w perspektywie narracji biograficznych, Wrocław 2010.

Green J., Sprawiedliwość w Dachau. Opowieść o procesach nazistów, tłum. M. Antosiewicz, Warszawa 2012.

Greif G., ...ptakaliśmy bez tez..., tłum. J. Kapłon, Warszawa-Oświęcim 2001.

Heger H., Mężczyźni z różowym trójkątem. Świadectwo homoseksualnego więźnia obozu koncentracyjnego 1939-1945, tłum. A. Rosenau, Warszawa 2016.

Karwowska B., Ciato, seksualność, obozy zagtady, Kraków 2009.

Kiedrzyńska W., Ravensbrück. Kobiecy obóz koncentracyjny, Warszawa 1961.

Kielar W., Anus mundi, Wrocław 2004.

Kubica H., Kobiety ciężarne i dzieci urodzone w KL Auschwitz, seria Gtosy Pamięci, Oświęcim 2010.

Levi P., Czy to jest cztowiek, tłum. H. Wiśniowska, Kraków 1978.

Majdanek 1941-1944, red. T. Mencel, Lublin 1991.

Michalak J., Nr 3273 miat szesnaście lat, Lublin 1979.

Millu L., Dymy Birkenau, tłum. K. Kabatc, E. Kabatc, Oświęcim 2007.

Morawiec A., Lagry w perspektywie genderowej, „Zagłada Żydów. Studia i Materiaty" 2010, nr 6.

Nikliborc A., Uwięzione w KL Auschwitz-Birkenau. Traumatyczne doświadczenie kobiet odzwierciedlone w dokumentach osobistych, Kraków 2010.

Pawełczyńska A., Wartości a przemoc, Warszawa 1995.

Posmysz Z., Królestwo za mgtą, Kraków 2017.

Reder R., Betżec, Kraków 1999.

Rhodes R., Mistrzowie śmierci. Einsatzgruppen, tłum. M. Urbański, Warszawa 2015.

Röger M., Wojenne związk, tłum. T. Dominiak, Warszawa 2016.

Ruszkowska S., Każdemu wtasna śmierć, Warszawa 2014.

Rutkowska-Kurcyuszowa M., Kamyki Dawida. Wspomnienia, Katowice 2005.

Stöcker-Sobelman J., Kobiety Holokaustu. Feministyczna perspektywa w badaniach nad Shoah, Warszawa 2012.

Szmaglewska S., Chleb i nadzieja, Warszawa 1960.

Theweleit K., Męskie fantazje, tłum. M. Falkowski, M. Herer, Warszawa 2015.

Truszkowska-Kuliniczowa A., Mój XX wiek. Wspomnienia, Szczecin 2004.

Wachsmann N., Historia nazistowskich obozów koncentracyjnych, tłum. M. Antosiewicz, Warszawa 2016.

Whitlock F., Bestie z Buchenwaldu, tłum. M. Fafiński, Zakrzewo 2014. 